This item was submitted to Loughborough's Research Repository by the author.

Items in Figshare are protected by copyright, with all rights reserved, unless otherwise indicated.

The political economy of information: Malawi under Kamuzu Banda, 19641994

PLEASE CITE THE PUBLISHED VERSION

PUBLISHER

(c) Elsevier

LICENCE

CC BY-NC-ND 4.0

REPOSITORY RECORD

Sturges, R. Paul. 2019. "The Political Economy of Information: Malawi Under Kamuzu Banda, 1964-1994". figshare. https://hdl.handle.net/2134/560. 


\title{
THE POLITICAL ECONOMY OF INFORMATION:
}

\author{
MALAWI UNDER KAMUZU BANDA, 1964-1994 ${ }^{1}$
}

\author{
Paul Sturges
}

Published in International Information and Library Review (1998), 30, pp185-201.

\section{INTRODUCTION}

Among information professionals generally there is a kind of bright optimism about the power and potential of information. This says, in effect, 'only provide information sufficiently and that will be enough'. Students will study better, citizens will live in a more secure and happy way, businessmen will maximise the effect of their investments, and governments will plan and administer in a rational fashion. The optimism goes further, to the point of arguing that as libraries hold information, they are sources of the power that information can unleash. Bacon's dictum that 'Knowledge itself is power', is taken in a very literal sense by the promoters of libraries: as if there were few, or even no, serious obstacles to the operation of this principle. ${ }^{1}$ When forced to explain why libraries are not more obviously effective sources of power, lack of funds and indifference by government are most commonly cited. It is as if a little more money and a little more attention from those in authority would change everything.

In fact, if the contention that information is power were reversed to say 'Power is information' it might better reflect reality. From this perspective, only what is generated by power relations has the status of information, and only through the exercise of power is the effect of information achieved. This draws attention to the underlying political economy of information: the ways in which power defines information, delimits it, governs its availability, pre-structures is effects. For the purposes of this essay, information is defined in a very broad way as: facts and ideas communicated. The term political economy is used in its more modern sense as: the study of the interrelation of economics, government and policy. ${ }^{2}$ Because the political economy of information can be seen in particularly stark outline in the context of developing countries, this essay concerns itself with Malawi under Kamuzu Banda.

\section{THE CASE OF MALAWI}

Kamuzu Banda, the leader of the Malawi Congress Party (MCP) and of Malawi itself since independence in 1964, became President for Life in 1970. Latterly he ruled in close association with John Tembo and Tembo's niece Tamanda Kadzamira. Grouped around them were the inner circle of the MCP, its youth wing, the Young Pioneers, and a wider entourage of business and political associates from within and outside Malawi. Banda and his supporters held power until his defeat in the elections of 1994. These were held under a multiparty system, which he had been coerced by international pressure into introducing in the previous year. The country he ruled is a small land-locked former British colony in south eastern Africa, with a population of about eight million. It was, and still is by most internationally accepted systems of measurement, one of the very poorest in the world with a

\footnotetext{
${ }^{1}$ The writing of this essay was prompted by some remarks of Evelyn Kerslake, a researcher in the Department of Information and Library Studies at Loughborough University. The author also wishes to thank Carolyn Pritchett of the Department of Information and Library Studies for bibliographical assistance.
} 
predominantly agricultural economy. ${ }^{3}$ Most farming is at subsistence level, but there is a market-oriented sector producing crops such as tea, tobacco and cotton. Malawi is also a considerable exporter of migrant labour. Banda's regime, though far from the most oppressive in twentieth century African history, was nevertheless one in which the state security apparatus enforced the power of a dictator and his elite with considerable ruthlessness. Banda himself followed a real politik which included unusually close ties with the South African apartheid regime.

At the same time, Malawi was generally accepted, though a little tentatively on occasion, in the international community. Representatives of the information professions carried on in the accepted modes of professional activity. Thus, discussion of the Unesco NATIS principles proceeded in Malawi in much the same way as in the rest of $\mathrm{Africa}^{4}$ and a wider world. The Malawi National Research Council discussed NATIS in April 1977 and an interim National Information committee was formed. One of the 'User Seminars' organised by the Deutsche Stiftung fur Internationale Entwicklung (DSE) to create a dialogue between librarians and government decision-makers so as to increase official awareness of the significance of information in the planning process, was held in Malawi in 1978, and by 1979 a survey of information resources and library collections had been carried out. Malawi's librarians had high hopes of this process, and Mphundi wrote of the "general and universal acceptability of the NATIS concept and objectives as the most appropriate manner of coping with the problem of the provision of information to those who require it in Malawi." ${ }^{5}$ By August 1983 a draft National Information Policy had been formulated. In the light of this Ngaunje, writing in 1986, felt able to suggest that "Prospects for the future look bright because Malawi is already looking at the NATIS concept and its implications in Malawi." ${ }^{6}$ However, he was well aware of the chief difficulty, as he pointed out that "In order to ensure the implementation of the information policy, a need exists for a high powered delegation from the government. In doing so, the importance of libraries can be impressed upon the officials." ${ }^{7}$ The irony of such suggestions is that the state had, since independence, systematically and formally intervened to prevent free flows of information.

\section{INFORMATION SUPPRESSION AND SURVEILLANCE}

The 1965 Public Security Regulations made it an offence, punishable by up to five years imprisonment to publish anything likely 'to undermine the authority of, or public confidence in, the government'. ${ }^{8}$ From 1973 life imprisonment was the penalty for sending 'false information' out of the country, and the president had personal powers to detain people without charge under the 1965 Regulations. The Censorship and Control of Entertainment Act of 1968 established a Censorship Board which prohibited works on various grounds, including 'the interests of public safety or public order'. ${ }^{9}$ Under this system the press was strictly controlled and journalists were regularly detained without charge for alleged offenses. There were only two newspapers published in the country, The Daily Times and Malawi News, both of which were government owned, as was the Malawi News Agency (MANA). Interestingly enough, the company through which Banda managed his financial dealings in Malawi was called Press Holdings. The radio service of the Malawi Broadcasting Corporation was likewise a channel for the government's version of information, and there was no television service. The MCP and its offshoots, like the Young Pioneers, had networks of communication which also passed on government-generated 'news'. The climate of fear in the country, and the energy with which critical comment from outside was fended off and countered have been well documented. As a visitor was told 'You know why Malawi is peaceful? Because we are taught to respect our elders, even from the time we are little children. We respect our parents, we respect our teachers, we respect those above us. All Malawians believe in unity, discipline, obedience. ${ }^{10}$ It is not the purpose of this essay to discuss the issue of censorship at length, but two particular effects are worth further mention.

The first is the way that this general climate influenced the working of information institutions, even 
without the specific intervention of the security system. Take for instance, a case reported by Diston Chirweza. ${ }^{11}$ In May 1983 three Government Ministers and another MP died, reputedly in a car accident, in one of the causes celebres of recent Malawian history. Copies of three newspapers (Guardian, UK, Times and Daily Mail, Zambia) had entered the country, despite containing claims that the victims were murdered. what is more, the newspapers were displayed in the periodicals section of the library at Chancellor College, Zomba. Students discovering this and desperate to read uncensored views of Malawian affairs, virtually fought in the periodicals section to obtain a sight of the copies. The librarians were then placed in a dilemma, which they resolved by withdrawing the offending copies, and requiring students from then on to sign for access to those newspapers. The librarians also read each arriving copy to try to determine whether it could be seen as subversive. As a result of this some further copies were also kept in store, with student access forbidden. At the time, it was widely believed that plain clothes security personnel were entering the library to monitor what was read. In effect what happened was that the librarians' fear of this led to them voluntarily extending the censorship system down to the practical library administration level.

The second is the way in which information was potentially affected by the power structures of the Malawian regime in ways that reached right back to its initial generation and expression. This was not merely relevant to overtly 'political' information, but included flows of 'neutral' information in practical and imaginative literature. Literature, for instance, was viewed by those in power in just the same way as other types of communication and it was marginalised and suppressed in ways equally insidious. Many of the books banned by the Censorship Board were literary and, indeed, Albert Muwalo (formerly Secretary General of the MCP) was tried in 1976 for possession of books including Orwell's Animal farm. More sinister yet was the imprisonment in 1987 of Jack Mapanje, poet and head of the English Department at the University of Malawi. The reason for his arrest was not made public, and he had never been identified with any political organisation or viewpoint. However, some of his more recent poems had criticised Banda and his entourage, and he was thought to be preparing further critical poems for publication. In prison Mapanje was denied writing materials, but kept his sanity and self-respect by composing poems in his head. Denied by his literate upbringing and schooling of the oral poet's exceptionally retentive memory, this method of composition virtually ensured that by his release in 1991, he had forgotten the content of what he had composed. ${ }^{12}$ The recall of titles and fragments of these poems enabled him to reconstruct them in freedom, but his work in its original form was gone. State power had thus effectively destroyed the information in Mapanje's poems at its source. The principle of this is important, because the same ability to influence whether information actually entered into public existence was exercised right through the system of government, through a pattern of non-censorship structural constraints.

\section{INFORMATION CAPACITY}

Every polity has its own particular capacity to generate and absorb information, built into the structure of its various institutions and agencies. It uses the information for administration and planning, publishing and disseminating it in various forms. Looking at Banda's Malawi, we see a system of administration and planning system, publicly directed towards national development, which naturally acquired and used information. ${ }^{13}$ This system was supposed to relate to longterm goals which had been articulated in the published Statement of Development Policies, ${ }^{14}$ A mechanism was then required to allocate resources to support the best possible choices of programmes to achieve these goals. The body notionally responsible for the policy-making aspect of this process, and chaired by the President himself, was the National Development Council. The various relevant ministries were represented in this, but in practice it only functioned between 1968 and 1973. The organ responsible for the actual coordination of the planning process was the National Development Planning Coordinating Committee. However, in practice the work of planning and much of what was supposed to be the responsibilities of the two committees 
actually came to take place in the Department of Economic Planning and Development, formed in 1985. The main flows of planning information into the Department came from the Treasury Department, which provided statistical projections for planning alternative, the Reserve Bank of Malawi, which forecasted financial developments, and the National Statistical Office, which provided estimates of Gross Domestic Product. In general terms, the Department had the obvious means for macro-economic planning available, and the data was put together in an annual budget document, the Economic Report.

The various ministries responsible for sectoral programmes and projects would then submit their estimates to the Department, where the usual process of measuring them against needs and resources was to take place. In addition, there was also a capacity for input from the regions via the system of District Development Committees, established in 1965. These were each chaired by the District Commissioner, who was the President's direct representative in the locality. Their membership included: government (representatives of the various ministries active in the District, notably Agriculture, Health and Education); politics (local MPs and officials of the MCP); the traditional authorities (chiefs and village headmen); an ADMARC (the official Agricultural Development and Marketing Corporation) representative; and various coopted members. The deliberations of these bodies were to lead to local development proposals, which could be transmitted direct to the Department.

The annual process also responded to various external factors. These were in fact products of uncertainties over the national income available for development purposes. In particular, agricultural exports were dependent upon commodity prices in world markets and vulnerable to problems with Malawi's transport routes through conflict-ridden Mozambique and unstable South Africa. Foreign aid, which contributed the other $85 \%$ of development funding, was also unpredictable when opinion in donor countries could reflect shifting levels of concern over the country's human rights record. Such uncertainties, and the difficulty of obtaining reliable intelligence for accurate prediction, encouraged an improvisatory planning process and a tendency to emphasize short-term interests.

Therefore a system which on the surface had the elements necessary for the incorporation of national, sectoral and local data, was not in practice capable of producing a consistent policy direction. This tendency was exacerbated by the concentration of power in the hands of the President and his immediate advisers. Since none of the planning bodies, including the Department, had the capacity for long or medium term decision-making, a de facto process of decentralisation to the Ministers and parastatal bodies occurred over time. This was not, however, really a decentralisation of decision-making, more a delegation of functions and routine administration to the bureaucracy. The planning process, and all the information-related elements of it, were thus basically relegated to an exercise in public budgeting, with the Ministries manoeuvring for a better share of the budget which the Treasury had set out. The only real opportunities for innovation were when the ear of the President could be gained.

With the significance of information thus reduced it is hardly surprising that the mechanisms for gathering, organising and interpreting information tended to fail to operate effectively. For instance, information about the rural areas was gathered by the Agro-Economic Survey (AES), which provided a continuing service to collect and organise baseline data. ${ }^{15}$ Data from the monitoring and evaluating of specific projects could then be set against AES data to give it context. The Survey's trained field enumerators and agricultural specialists collected and processed data, producing a steady flow of documentation. This contained precisely the detail of topography, soils, vegetation, climate and rainfall, infrastructure, settlement patterns and farming practices that had been identified as a need by Stolper in his famous comments on the relation of information to planning in Africa in the 1960s. ${ }^{16}$

However, the users of this baseline data gradually began to suggest that it was becoming detached from the planning requirements of the Ministries. The process seems to have become academic, producing information which was interesting in its own right, but not always giving direct answers to the questions 
planners were asking. This was arguably a symptom of a systemic inability of the government datagathering system at large to absorb data in a way which would allow it to react at short notice to the needs of those planning and administering projects. Suggestions that dialogue between users and collectors of data (such as the AES) could reduce such difficulties were no doubt sensible enough. The chances of such a dialogue being really effective when the core of the planning system effectively favoured self-interested political manoeuvring in preference to a rational, information-based decisionmaking process seem limited however.

Such a systemic failure of the information-gathering process is shown up particularly clearly in relation to the occurrence of disasters. The recognition that a capacity to anticipate and react to disasters is a vital function of government is a fairly recent phenomenon in the less developed countries, such as Malawi, which are most vulnerable to them. A very large proportion of the population lives at a level which offers little margin for adjustment when the droughts, floods, earthquakes, epidemics or human conflicts, to which the regions in which they are situated are particularly prone, occur. Not only is the ability to marshal assistance, in the form of emergency supplies of medical necessities, foodstuffs, shelter and clothing, usually inadequate, but the sheer ability to collect, organise and interpret data relating to disasters is lacking. An occurrence of disaster in the Nkhata Bay area of Malawi in 1986 illustrates this last point. ${ }^{17}$

Nkhata Bay is untypical of most of the rest of Malawi, where the staple nsima (maize porridge) is regarded with a quasi-religious enthusiasm, and where rice is also widely consumed as an alternative. The staple around Nkhata Bay is cassava, and in 1986 mealy bug infestation virtually destroyed the crop. The devastating effects of this on a community living at around subsistence level can be imagined, but for a damagingly long period this failed to enter official cognisance. Informal reports of higher than usual death rates in the area were the first signal of the disaster to be noticed. By then, of course, the damage was already largely done. It is important to note that this was not happening in an area where the population was incapable of communicating its needs. Nkhata Bay has literacy levels amongst the highest in the country, and a high take up of literacy programmes. The question which has to asked is how, in a community of this kind, distress could reach such an advanced stage before authority was put in a position to react.

Some of the answer to this question is to be found at an institutional level, and is common to Malawi and many other less-developed countries. It arises from the persistently top-down nature of rural communication through extension systems. ${ }^{18}$ These systems, originally set up to communicate agricultural information to farming communities, place low ranking government officials, the extension agents, in close contact with even the very smallest units of rural settlement. Although the services function first and foremost to disseminate information into the community, it is also expected that extension systems will convey information out of the community for use by the administration. For instance, estimates of crop yields in many countries are compiled to a large extent from reports based on the observation of extension agents as they tread the roads between the villages and hamlets of their client area and talk to the farmers they serve. The reliability of this kind of data collection is moderated by the agents' powers of observation and willingness to apply themselves to the task. It is also governed by the extent to which farmers wish to conceal the true nature of their output, to avoid taxation and credit repayments, or merely to preserve some measure of control of their own circumstances by limiting outside knowledge of their personal and community affairs.

The failure of extension systems to establish effective bottom-up information flows has often been remarked upon. The political economy of this has been less frequently identified, but the Nkhata Bay case shows it with considerable clarity. The people of the area are of the Tumbuka/Tonga language group and were thus not part of the favoured circle in Malawian society. Although faced with considerable suffering in the form of malnutrition and consequent high mortality, local leaders seem to 
have avoided communicating the facts of the matter to government representatives. Their prior awareness of their government's sensitivity about national and international perceptions of foodshortages and their public health consequences cannot be doubted. They also knew that complaints from their quarter could be received with some impatience and might be treated as indications of dissidence. Kamuzu Banda's frequent assertions to the effect that 'my people have food in their stomach, a shirt on their back and sleep under a roof that does not leak ${ }^{19}$ were certainly universally known. Add to this the fact that the area was not politically favoured and lacked direct links to the ears of those with influence, and the anatomy of a disaster is more clearly revealed. The problem was a compound of the inbuilt inadequacies of information feedback mechanisms from the localities and the more specific powerrelated inhibitors of communication in play on this occasion. Between them these forces prevented information, of a particularly urgent kind, from even entering the system. If a system implicitly rejects information; in effect, refuses to define it as information, then disaster of the kind that afflicted Nkhata Bay is a predictable consequence. The Malawian system not only rejected information from this, and many other sources, but it denied access to the information which was within the system to whole segments of the population.

\section{ACCESS AND LIMITATIONS TO ACCESS}

Power relations govern access to information in a variety of ways, usually to the benefit or detriment of parts of the population variously identified by characteristics such as gender, financial status, ethnicity, religion, economic activity, not to mention class or political persuasion. The ways in which levels of access are granted and denied include fairly obvious means such as control of the educational system, choices over the use of languages, and geographical distribution of the infrastructure needed for access. It also includes some very specifically local means. It is probably true to say that every polity differentiates between groups in different ways and mediates access by different combinations of means. Malawi is thus only an example of a broad general rule, not necessarily typical, or even absolutely unique.

The power of the Malawian regime was rooted in an alliance with the Chichewa-speaking people of the central regions. Indeed in the months after the elections of 1994, people in this area would frequently voice anxiety about the consequences of the multiparty system and the freedom of expression that it had brought with it. ${ }^{20}$ In contrast, the votes of the Tumbuka-speaking people of the north, and the Yaospeakers of the south had been the means of unseating Banda, and their attitude to freedom of expression was naturally much more positive. The regime had attempted to counter the perceived dominance of official posts by the often better educated Tumbuka-speakers on a number of occasions, as following the February 1989 speech in which Banda accused northern teachers employed in other regions of deliberately teaching badly to hinder the academic progress of students from those regions. In a rather eccentric way he was identifying information, in the form of educational content, as crucially close to the surface of power relations.

The Chichewa-speaking voters of the central regions needed to be rewarded for their loyalty, and the rewards came in many forms, including major infrastructure projects. Hence, the siting of Lilongwe, the new national capital, after 1975, in this region. The building and supply contracts, the employment opportunities at all levels, the closer access to government and officials, were all brought to the favoured region. Prestige projects such as Kamuzu International Airport, which sits in lonely splendour 26 kilometres north of the city awaiting its pitifully few flights per day, came with the capital. The rewards for support might, or might not, have an identifiable information facet. Thus the adult literacy programme, ostensibly open to all with instruction in the various local languages, was effectively arrogated to the regime's power base by the restriction of the learning materials to the Chichewa language medium. ${ }^{21}$ 
The penalties experienced by those excluded from the alliance upon which power was built also varied in interesting, and often information-related, ways. For a group which was wholly rejected, such as the Jehovah's witnesses who were banned in 1967, the consequences could be horrific. In 1972 a number of members were killed in pogroms and an estimated 20,000 fled into Zambian exile. The mainly Muslim Yao people, whilst they did not suffer in this way, certainly experienced even poorer access to the educational system, and therefore the information benefits following on from education, than the rest of the population. This was engineered through the strong association between the best quality education and Christian, and more specifically Presbyterian Protestant, schools. The converse of this was that the comparatively favoured Christian population tended to feel more attached to the regime, until, that is, the local Catholic Church hierarchy memorably spoke out and began Banda's downward slide to defeat in 1994.

The regime was not however tied merely to a regional and language-related base of support. The Life President and his associates succeeded to a considerable extent in developing a class base of those with a stake in the system. Those included were "indigenous commercial farmers, distribution and retail entrepreneurs, the political elite, top bureaucrats and the top management in statutory bodies." ${ }^{22}$ The ways in which the structures of the state were manipulated to build up and main this base of support were numerous and ranged from the open brutality of the MCP Young Pioneers towards political outsiders, to the direction of flows of strategically valuable information towards the favoured.

The education system was, as suggested already, one means for modulating this. Access to education, and thus eventually to the professional and official posts which awaited those able to succeed educationally, was unusually restricted in Banda's Malawi, compared with the great majority of other African countries. The enrolment in primary schools in the 1990s had only recently passed 50 percent of the child population, despite the introduction of an official policy of open access to primary education. The policy resulted in an average pupil-teacher ratio of 69:1 in state schools and further enhanced the value of the educational provision by religious denominations. The system narrowed even further at secondary school level with only a 4 percent enrolment, and in higher education it fell to 0.3 percent. That the selection represented by such a system was to a considerable degree based on talent is evidenced by the excellent qualities of the Malawian professional classes, but the ability of the system to filter for social and political acceptability is also clear.

Even more specifically than this, information was used as a means to advance the interests of those who were included within the business connections of the regime, and the ramifications of this are worth illustrating in some detail. The two pillars of the rural economy were production of cash crops for export, and the export of migrant labour. The regime appreciated that the two could be facilitated by providing services of various kinds to commercial agriculture and neglecting traditional subsistence farming so as to reinforce its role as a reservoir of cheap labour. Land was dispensed for estate agriculture through grants and sales, and credit and other support was provided to support commercial agriculture. Estate farmers were generally allowed to market their own output, but other producers were obliged to use the Agricultural Development and Marketing Corporation (ADMARC). The difference between the prices ADMARC paid small farmers for their output and the prices at which ADMARC could sell in export markets constituted a considerable surplus extracted from the small farmers for the government. Thus while the major producers operated with market information, the peasants operated under the less than helpful tutelage of an agency of the regime.

There is also clear evidence that market-oriented smaller farmers were explicitly targeted as the recipients of agricultural information flows, credit and other assistance, in effect at the expense of their subsistence-farming neighbours. For the top $25 \%$ of farming families only, "the emphasis will be on the intensification and diversification of cash crop production by means of improved extension advice, ox- 
mechanisation, credit access, and marketing services." ${ }^{23}$ Of the rest of the farming population, it has been pointed out that "Indeed the government has at times even cynically remarked that households in the bottom two groups can learn by listening to the radio or emulating their better-endowed and bettersupported neighbours in the top group. Thus data from the Annual Survey of Agriculture 1984-85 showed that the rate of exposure to extension services ranged between 13.2 percent to 28.2 percent for the bottom two groups of smallholder households, while that of the top group ranged from 40.6 percent to 52 percent." ${ }^{24}$ The underpaid and under-supported extension agents trudging the dirt roads to give their talks and demonstrations no doubt felt some relief that there was implicit endorsement of a de facto lightening of their client-loading.

Perhaps the most significant thing about such mechanisms is that neither the extension agents or the farmers themselves fully perceive the extent to which the real and apparent agendas of a service like agricultural extension differ from each other. When asked, in the form of a questionnaire or structured interview, they generally express satisfaction with the system and its effects. Thus, Mpachika in reporting a survey which produced just such an endorsement of the system, was only able to identify one serious criticism. Farmers "are not sufficiently involved in deciding points to be discussed by the extension workers on field visits, nor in the extension program planning process." ${ }^{25}$ In fact, by allowing farmers to talk in a comparatively unprompted, loosely structured way about their perceptions of the information services available to them, it is possible to discover that this one concern actually points in the direction of a group of deep-seated concerns about the effectiveness of rural communication systems. ${ }^{26}$

The point seems to be that the farmers are happy with the principle of a service conveying information to them orally, but perceive the actual service as in crisis. What they do not identify particularly strongly is that the operation of the system is implicitly skewed towards the needs of market-oriented farmers. Other information services make only minor differences to this pattern. Alongside the extension system, the Malawi National Library Service operates a network of rural information centres. These little collections of simple reading materials in Chichewa are very worthy, the librarians are committed to equal access to the service for all, and communities are very proud of them. However, written material is of only indirect use to the nonliterate majority of the rural population, and not much more use to those who cannot read Chichewa. Looked at in terms of its total contribution, this service may seem like only a beginning.

Academic researchers have also failed to perceive this, and have talked as if some adjustments to a malfunctioning but essentially neutral system are all that is needed to improve the rural person's lot. Thus, Dorward in 1991 experimented in Malawi with a system that developed rules for farmers' decision-making. ${ }^{27}$ It was intended that "the individual component rules may then provide a medium for the communication of technical information" that would be timely and appropriate. All this took no account of the way in which the decision-making process, however well-structured, could be rendered ineffective by the structural imperfections of the delivery systems identified above. The point about information and related flows to farmers in Malawi, was that they served a group of power-related imperatives not generally visible when information was looked at as a discrete element. What is more, the pattern of landholding and farming in Malawi is such that the effects of this fell disproportionately across the community in various other ways, notably relation to gender. This is not particularly surprising in view of the status of women in Malawi.

The role of the Malawian woman has traditionally been one of subservience to the man. She is regarded as his sexual servant, spending hours in youth preparing her genitals for his particular delight, culturally conditioned to grant sexual access whether particularly willing or not, linked to a husband in a marriage relationship described by a word meaning sexual intercourse. In traditional communities a woman will still not presume to meet the eye of a man in discussion and will still often greet a caller at her home in a semi-kneeling crouch of obeisance. The Malawian regime reinforced this unequal power relationship: 
Banda's close companion Tamanda Kadzamira, despite her influence, was demeaned as the 'Official Hostess', and the Life President travelled with an entourage of uniformed women who literally danced attendance on him. Kadzamira was also charged with mobilising female support for the regime, as head of Chitukuko Cha Amai M'Malawi, the officially recognised women's organisation. The life of women generally was hedged about with regulations such as that allowing them to be imprisoned for up to six months for wearing trousers.

Access to education, and therefore access to information in written or other technically complex forms that require formal education was disproportionately available to males. Relatively fewer girls were enrolled for formal education in comparison with boys. ${ }^{28}$ Thus in 1988, whilst only just under $53 \%$ of children aged 6-13 were enrolled in schools, the rate for boys was actually $55 \%$ and for girls, $50 \%$. This difference became more pronounced at secondary level, where only $4 \%$ of the $14-17$ year-olds were enrolled, and of that tiny number, only $44 \%$ were girls. The number of Malawians studying at university was only $0.3 \%$, of whom just over $20 \%$ were female in 1990 . As an indicator of the pent-up desire for education this created, one can cite the approximately $90 \%$ female enrolment in adult literacy programmes. ${ }^{29}$

Access to significant information sources which were orally delivered was also denied to women in even more subtle ways. This was despite the economic significance of their work, particularly in the agricultural and petty capitalism sectors. Female-headed households are disproportionately important in many African societies, not least that of Malawi, with an estimated 28\% female-headed rural households, because of such factors as migrant work by men. In addition, women make most of the decisions relating to farming activity in many male-headed households where the men are mainly concerned with nonfarming economic activities, such as trading, fishing and salaried jobs. Rural development efforts, in the form of credit, technology, advisory and other forms of institutional support, have tended to be aimed at those producing cash crops (mainly men), rather than those engaged in subsistence (mainly women).

Research studies have shown that productivity-raising innovations tend not to be universally adopted in the rural areas precisely because female-headed households are neglected in the diffusion process. Thus when in the late 1970s fire-cured tobacco production and improved maize varieties were introduced in the Lilongwe region, "Of the 160 households sampled [in a 1980-1 survey] none of the 26 femaleheaded households (16\% of the sample) grew any tobacco at all, while only two grew improved maize." ${ }^{30}$ The mechanism behind this was that female-headed households generally had smaller holdings and fewer people available to work the land. The women were consequently less willing to commit themselves to the credit arrangements that might help in implementing innovations, but which conversely might produce all the dis-benefits of indebtedness. Since both credits and agricultural advice service tended to be routed through farmers clubs as combined packages at this time, the female farmers were effectively denied access to information because of their weak credit position. Their situation effectively sums up the way in which a combination of economic and policy factors effectively position any particular sector of society in information terms. This positioning then overwhelms the working of formal equality of access in law, and tends to negate the potential benefits of any open and untargeted information provision, such as free public library service.

\section{CONCLUSION}

This discussion of information in terms of economic and power relations subverts the facile equation of information and libraries with power. Lulled by an unrealistic faith in the ultimate rightness of their efforts, information and library professionals work to an agenda usually structured around the need for more documents, better paid and better trained staff, and the introduction of information technology. The fact is that the agenda is painfully naive when discussed in its own terms: more documents are not likely 
to help unless they are have appropriate content; existing staff could achieve much more if better deployed and directed; and information technology is an absurdity in the context of tiny, underused and ill-targeted information and library services. When looked at in terms of real structures of power and the implicit agendas of governments, it can be seen as even further detached from hard reality. That surveillance and censorship rank higher in priority than intelligence gathering for development planning, or information dissemination to the citizen, for governments like those of Banda and very many others in the present day, can be demonstrated in detail. The agendas of those in power are indeed all too frequently at odds with that of those who hope to achieve some social amelioration through information and library work.

There is quite simply little to be gained from heeding the frequent cry that information and library professionals must persuade the decision makers, that they must be promoters and publicists. Again, just looked at in its own terms this is unconvincing. Should professionals who were not recruited because they wanted to take on the world single-handed, who took up information jobs precisely because they preferred to contribute to the steady progress by tiny increments that the library offers society, seriously be expected batter their way into the counsels of the powerful? The suggestion is ridiculous. If there is any message at all to be drawn out of this brief glance at the political economy of information through the case of one country, it is that the starting point for an effective agenda is in a hardheaded assessment of the practical and the achievable. An analysis of the actual dynamics of information in a country is capable of pointing to a series of strategies which are both compatible with the essential purposes of information and library work, in accord with the ostensible policy aims of those in power, and directed towards genuinely achievable aims. For instance, the Malawian government never actually said that it wanted to disadvantage women in information terms, even though it did in practice. Such an unspoken tendency cannot be defeated with a frontal attack by librarians flourishing their high principles. A subtler strategy directed at overturning individual aspects of the problem is needed and that has to be based in a clearsighted analysis of just what the structure of the problem is. Until information and library professionals can offer such analyses, their frustrations are likely to continue. 


\section{NOTES}

1.The best known version of this viewpoint is probably - Thompson, J. Library power: a new philosophy of librarianship. Clive Bingley, 1974.

2.The origins of this usage can be found in Maurice Dobb's assertion that political economy is "Answers to certain questions of an essentially practical kind - questions concerning the nature and behaviour of the economic system which we know as capitalism." Dobb, M. Political economy and capitalism Routledge, 1937. p.vii

3.Vail, L. Peasants, migrants and plantations: a study of the growth of Malawi's economy. Journal of Social Science, 11(1), 1984 pp.1-36.

4. Mchombu, K.J. and Miti, K. Formulation of National Information Policies in Africa: some unlearnt lessons. International Information and Library Review 24(2)4., 1992 pp.139-171.

5.Mphundi, B.G. A conceptual framework towards a National Information System for Malawi. MALA Bulletin 2(1) 1981 pp.16-33. 26.

6. Ngaunje, M.A. NATIS in Malawi. MALA Bulletin 4(2), 1986 pp. 37-43. 41.

7.Ibid. 38.

8.Article 19, Information, freedom and censorship: world report 1991. Library Association Publishing, 1991. 27.

9.In the first ten years of this system, 840 books, 100 periodicals and 16 films were banned.

10.Maja-Pearce, A. Malawi. Index on Censorship, 4, 1992 pp.52-57. 56.

11. Chiweza, D.S. Information and politics: limits and ambiguity of the concept of freedom of information in the Malawi of 1961-1993. In: Msiska, A. et al eds. Proceedings of the Eleventh Standing Conference of Eastern, Central and Southern African Librarians, Blantyre, Malawi, 25-29 July 1994. Zomba, Malawi Library association, 1995. pp.35-49.

12.Author's conversation with Jack Mapanje, London, 28th Mar 1995.

13.Kaunda, J. The administrative organisation and processes of national development planning in Malawi. In: Mhone, G.C.Z. ed. Malawi at the crossroads: the post-colonial political economy, Harare, Sapes Books, 1992. pp.50-89.

14.Malawi Government, Statement of development policies 1987-1996. Zomba, Government Printer, 1988.

15.Green, D.A.G. and Maddock, N. Facts for planning rural development: some lessons in the administration of data collection from Malawi. Agricultural Administration and Extension 24, 1987, pp.33-48. 
16.Stolper, W.F. Planning without facts: lessons in resource allocation from Nigeria's development. Cambridge, Mass., Harvard University Press, 1966.

17.Pelletier, D.L. and Msukwa, L.A.H. Role of information systems in decision-making following disasters. Human Organisation, 49(3) 1990 pp.245-254.

18.Van den Ban, A.W. and Hawkins, H.S. Agricultural extension, Longman Scientific and Technical, 1988.

19. Mhone, G.C.Z. The political economy of Malawi: an overview. In: Mhone op. cit. pp.1-33. 10.

20.Sturges, P. Visit to a new Malawi, July 1994. In: Turfan, B. ed. Emerging democracies and freedom of information. London: Library Association Publishing, 1995. pp.21-23.

21.Kishindo, P. The functional literacy programme in Malawi: educating adults for improved standards of living. Journal of Social Development in Africa, 9(1) 1994 pp.19-26.

22.Mhone, G.C.Z. The political ecomony of Malawi: an overview. In: Mhone op. cit. p.5.

23.Malawi Government, Statement of Development Policies, 1987-1996. Zomba, Government Printer, 1988.

24.Mhone op. cit. p.19.

25.Mpachika, E.D. et al. Contact farmers voice opinions: T and V system of extension in Malawi. Journal of Extension Systems 6(1) 1990 pp.67-73. 72.

26.Sturges, P. and Chimseu, G. The chain of information provision in the villages of Malawi: a rapid rural appraisal. International Information and Library Review 28, 1996 pp.135-156.

27. Dorward, A, Integrated decision rules as farm management tools in smallholder agriculture in Malawi. Journal of Agricultural Economics 42(2), 1991 pp.146-160.

28.Statistics from Moyo, C.M. Formal education policy and strategy in Malawi, 19641990. In: Mhone op. cit. pp.265-297.

29.Kishindo, P. op. cit. p.23.

30.Chipande, G.H.R. Innovation adoption among female-headed households: the case of Malawi. Development and Change 18, 1987 pp.313-327. 318. 